Perbedaan Fear of Failure pada Mahasiswa Bidikmisi ditinjau dari Jenis Kelamin

Proyeksi, Vol. 16 (2) 2021, 174-182

\title{
PERBEDAAN FEAR OF FAILURE PADA MAHASISWA BIDIKMISI DITINJAU DARI JENIS KELAMIN
}

\author{
Firman Firdaus Nuzula ${ }^{1}$, Dahlia ${ }^{2}$, Afriani $^{3}$, dan Zaujatul Amna ${ }^{4}$ \\ 1,2,3,4 Program Studi Psikologi Fakultas Kedokteran Universitas Syiah Kuala, Banda Aceh \\ E-mail: firmannuzula@gmail.com,dahlia@unsyiah.ac.id*
}

\begin{abstract}
Abstrak
Mahasiswa Bidikmisi mempunyai kewajiban dan tantangan yang berbeda dengan mahasiswa regular (bukan penerima Bidikmisi). Kewajiban yang harus dipenuhi oleh mahasiswa Bidikmisi berpotensi menimbulkan kecemasan. Kecemasan yang dirasakan mahasiswa Bidikmisi dalam memenuhi tantangan dan kewajiban tersebut menandakan adanya indikasi perasaan fear of failure. Penelitian ini memiliki tujuan untuk mengetahui perbedaan fear of failure pada mahasiswa Bidikmisi di Universitas Syiah Kuala yang ditinjau dari jenis kelamin. Populasi dalam penelitian ini adalah mahasiswa Bidikmisi Universitas Syiah Kuala yang berdomisili di Banda Aceh dan Aceh Besar. Teknik penentuan sampel menggunakan simple random sampling. Pada penelitian ini menggunakan 340 orang sebagai responden yang terdiri dari 170 laki-laki dan 170 perempuan. Teknik pengumpulan data menggunakan skala yang disusun oleh Conroy (2002) yaitu The Performance Failure Appraisal Inventory (PFAI). Penelitian ini menggunakan teknik Independent Sample T-test sebagai analisis data dan hasilnya menunjukkan signifikansi $(p)=0,511 \quad(p>0,05)$. Hasil signifikansi tersebut menyimpulkan bahwa tidak ada perbedaan fear of failure pada mahasiswa Bidikmisi antara mahasiswa Bidikmisi laki-laki dan perempuan. Tidak adanya perbedaan tersebut disebabkan oleh faktor prestasi yang dicapai oleh mahasiswa Bidikmisi, dan kebijakan netral dalam lembaga pendidikan yang tidak dapat ditentukan oleh jenis kelamin.
\end{abstract}

Kata Kunci: Fear of Failure; Bidikmisi; Jenis Kelamin

\section{GENDER-BASED DIFFERENCES IN FEAR OF FAILURE AMONG BIDIKMISI STUDENTS}

\begin{abstract}
Bidikmisi students have different obligations and challenges than regular students (not Bidikmisi recipients). The obligations that must be fulfilled by students of Bidikmisi have the potential to cause anxiety. The anxiety felt by Bidikmisi students in meeting these challenges and obligations indicates an indication of fear of failure. The purpose of the study was to find out the differences in fear of failure in Bidikmisi students at Syiah Kuala University who were reviewed from gender. The population in this study was Students of Bidikmisi Syiah Kuala University domiciled in Banda Aceh and Aceh Besar. Sampling techniques using simple random sampling. In this study, 340 people were used as respondents consisting of 170 men and 170 women. Data collection techniques using a scale compiled by Conroy (2002) namely The Performance Failure Appraisal Inventory (PFAI). This study used an Independent Sample T-test as a data analysis and the result showed significance $(p)=0.511(p>0.05)$. The results concluded that there was no difference in fear of failure in Bidikmisi students between male and female Bidikmisi students. The absence of such differences is due to the achievement factors achieved by Bidikmisi students, and neutral policies in educational institutions that cannot be determined by gender.
\end{abstract}

Keywords: Fear of Failure; Bidikmisi; Gender

174 
Firman Firdaus Nuzula, Dahlia, Afriani, dan Zaujatul Amna

\section{Pendahuluan}

Pemerintah memberikan kemudahan bagi warganya untuk mendapatkan pendidikan berupa bantuan dana bagi peserta didik yang berprestasi yang memiliki keterbatasan ekonomi (UU Republik Indonesia No.20, 2003). Tunjangan yang diberikan kepada pelajar atau mahasiswa sebagai bantuan biaya belajar disebut beasiswa (Kamus Besar Bahasa Indonesia, 2005). Berbagai jenis beasiswa ditawarkan di perguruan tinggi. Jenis beasiswa yang diberikan berdasarkan pihak penyedia yang terbagi dalam lima kategori, salah satu dari kategori tersebut bersumber dari pemerintahan (Fernanda, 2017). Adapun salah satu beasiswa yang diterima oleh mahasiswa yaitu beasiswa Bantuan Biaya Pendidikan Mahasiswa Miskin Berprestasi (BIDIKMISI). Kementerian Riset, Teknologi dan Pendidikan Tinggi (2019) menjelaskan bahwa Bidikmisi adalah bantuan biaya pendidikan dari pemerintah bagi lulusan Sekolah Menengah Atas (SMA) atau sederajat yang memiliki potensi akademik baik tetapi memiliki keterbatasan ekonomi.

Mahasiswa Bidikmisi mempunyai tantangan yang berbeda dengan mahasiswa regular (bukan penerima Bidikmisi). Hal ini bisa dilihat dari kewajiban yang harus dipenuhi oleh mahasiswa Bidikmisi. Kewajiban mahasiswa Bidikmisi di Universitas Syiah Kuala (USK) adalah harus mempertahankan Indeks Prestasi Kumulatif (IPK) minimal 2,75 untuk bisa melanjutkan studinya dengan status sebagai mahasiswa penerima Bidikmisi (Takriyuddin, Mukmin \& Yunus, 2016). Berdasarkan wawancara personal yang dilakukan peneliti pada 8 mahasiswa Bidikmisi, peneliti mendapat informasi bahwa Bidikmisi di USK akan dicabut jika mahasiswa mengurus beasiswa lain, berkas pengajuan terbukti palsu, mengajukan cuti akademik, mahasiswa menggunakan barang-barang yang mahal, tidak mengikuti peraturan USK atau program Bidikmisi, tidak tinggal di asrama USK selama satu tahun, dan performa akademik mahasiswa menurun seperti mendapat Indeks Prestasi (IP) dibawah 2,75.

Tantangan yang tidak dapat dicapai dengan baik akan berdampak negatif bagi individu tersebut sehingga menimbulkan ketidakmampuan yang dapat mendorong individu tersebut melakukan penghindaran (Darwin dalam Mobbs \& Hagan, 2015). Hal tersebut mendorong individu untuk berperilaku menghindar karena rasa takut. Rasa takut merupakan sikap penolakan yang kuat untuk menjahui benda, tempat, orang dan aktivitas yang memberikan tekanan (Kalar \& Mustahsan, 2013). Salah satu jenis rasa takut adalah rasa takut akan kegagalan yang disebut dengan istilah fear of failure yang secara definisi merupakan sebuah reaksi individu sebagai bentuk antisipasi terhadap konsekuensi tidak menyenangkan yang akan terjadi (Conroy, 2001).

Fear of failure bisa didefinisikan sebagai sebuah reaksi antisipasi terhadap konsekuensi tidak menyenangkan yang diprediksi akan terjadi akibat kegagalan yang dialami oleh individu (Conroy, 2001). Menurut Elliot dan Thrash (2004) sebagian besar individu yang berada dalam kondisi di ruangan kelas, di lapangan bola dan tempat kerja dimotivasi oleh keinginan untuk menghindari kegagalan. Fear of failure juga dapat menimbulkan dampak negatif sehingga dapat membuat hilangnya motivasi, meliputi motivasi intrinsik, kegigihan, usaha yang dikeluarkan, pilihan tugas, performansi dan kesejahteraan (Nainggolan, 2007). Mahasiswa yang berada dalam kondisi ketakutan melaporkan bahwa saat ujian mereka seolah-olah tidak mengingat pelajaran yang telah dipelajari sebelumnya dan merasakan hambatan dalam mengingat atau kemampuan untuk memunculkan kembali materi (Davidoff, 1991). Menurut Zulkarnain dan Novliadi (2009), mahasiswa yang memiliki motivasi prestasi tinggi dapat menunjukkan perilaku yang berpotensi untuk berprestasi dalam akademik. Sebaliknya jika mahasiswa memiliki fear of failure dalam menghadapi ujian, walaupun mahasiswa tersebut memiliki 
Perbedaan Fear of Failure pada Mahasiswa Bidikmisi ditinjau dari Jenis Kelamin

Proyeksi, Vol. 16 (2) 2021, 174-182

motivasi untuk berprestasi, mahasiswa akan mengalami kesulitan untuk meraih prestasi dengan optimal.

Perasaan fear of failure yang terjadi pada laki-laki dan perempuan memiliki tingkatan yang beragam. Penelitian yang dilakukan Minnaert dan Janssen (1997), Nelson, Newman, Mcdaniel, dan Bulboltz (2013) menunjukan bahwa perempuan memiliki fear of failure yang lebih tinggi dibandingkan laki-laki. Hasil berbeda yang ditemukan pada penelitian yang dilakukan oleh Fried-Buchalter (1997) dan Husna (2015) yang menunjukkan bahwa laki-laki memiliki tingkat fear of failure lebih tinggi dibandingkan dengan perempuan. Penelitian yang lain mendapati hasil yang berbeda dibandingkan penelitian sebelumnya. Penelitian yang dilakukan oleh Sagar, Boardly dan Kavussanu (2011) menunjukkan bahwa tidak ada perbedaan fear of failure pada atlet laki-laki dan atlet perempuan di Universitas British. Selajutnya hasil yang sama ditemukan oleh Fitrianda (2019) yang menemukan bahwa tidak ada perbedaan fear of failure pada mahasiswa laki-laki dan perempuan fakultas Teknik di Univeritas Syiah Kuala, hal tersebut disebabkan oleh tingginya efikasi diri pada perempuan untuk terlibat dalam bidang Teknik. Hasil sejalan ditemukan oleh Hendra (2019) yang dalam analisis tambahannya menunjukan bahwa tidak terdapat perbedaan fear of failure antara atlet laki-laki dan perempuan di Kota Banda Aceh. Tidak adanya perbedaan fear of failure antara laki-laki dan perempuan pada temuan tersebut dikarenakan dorongan motivasi berprestasi pada setiap atlet, serta baik atlet perempuan maupun laki-laki merasa memiliki kemampuan terbaik dalam dirinya.

Berdasarkan uraian data dan fenomena yang telah dijelaskan di atas dapat disimpulkan bahwa fear of failure memiliki hasil dan tingkatan yang beragam yang terjadi pada laki-laki dan perempuan.

\section{Tinjauan Teori}

\section{Fear of Failure}

Conroy (2001) mendefinisikan fear of failure sebagai sebuah reaksi antisipasi terhadap konsekuensi tidak menyenangkan yang akan terjadi akibat kegagalan yang dialami oleh individu. Conroy (2001) menjelaskan bahwa terdapat 5 (lima) dimensi ketakutan akan kegagalan, yaitu ketakutan akan perasaan hina dan rasa malu (fear of shame and embarrassment), ketakutan akan penurunan estimasi diri (fear of devaluing one's self- estimate), ketakutan akan hilangnya pengaruh sosial (fear of losing social influence), ketakutan akan ketidakpastian masa depan (fear of having an uncertainfuture), dan ketakutan akan mengecewakan orang yang penting baginya (fear of upsetting important others).

Menurut Conroy, Poczwardowski, dan Henschen (2001), terdapat konsekuensi negatif dan positif yang akan didapatkan oleh individu yang mengalami fear of failure. Adapun konsekuensi negatif pada individu yang merasakan fear of failure sebagai berikut, individu merasa kehilangan dan kalah, individu merasa kehilangan kontrol, perubahan dalam hubungan interpersonal, konsekuensi secara emosional, menyalahkan diri sendiri, dan individu merasa malu. Selanjutnya konskuensi positif yang didapatkan bagi individu yang merasakan fear of failure adalah menjadi salah satu pemicu untuk belajar dari kegagalan, individu akan mendapatkan dukungan dari lingkungan sosial atas kegagalan yang dialami.

\section{Jenis Kelamin}

Jenis kelamin merupakan istilah biologis yang berfungsi untuk membedakan anatomi atau bentuk tubuh antara laki-laki dan perempuan. Dalam masing-masing istilah biologis tersebut, terdapat gender 
Firman Firdaus Nuzula, Dahlia, Afriani, dan Zaujatul Amna

yang merujuk pada segala sesuatu yang berkaitan dengan jenis kelamin, peran, dan tingkah laku individu (Baron \& Byrne, 2004). Pada pengertian lain menjelaskan jenis kelamin adalah salah satu bentuk pengkategorian dasar dalam kehidupan sosial berupa maskulin dan feminin. Secara umum jenis kelamin dikategorikan dalam dua jenis yaitu jenis kelamin laki-laki dan jenis kelamin perempuan (Taylor, Peplau, \& Sears, 2009).

\section{Metode Penelitian}

Penelitian ini menggunakan pendekatan kuantitatif dengan metode penelitian komparasi. Penelitian melibatkan 340 sampel dengan karakteristik yaitu; mahasiswa Universitas Syiah Kuala dari 12 fakultas, aktif kuliah atau sedang tidak dalam masa cuti, mahasiswa penerima Bidikmisi, berdomisili di Banda Aceh dan Aceh Besar, bersedia menjadi subjek penelitian. Skala yang digunakan untuk melihat fear of failure subjek pada penelitian ini adalah Performance Failure Appraisal Inventory (PFAl) yang disusun oleh Conroy (2001).

Penelitian diawali dengan menyiapkan alat ukur, melakukan expert review, melakukan pengujian skala (try out), mengajukan protokol etik penelitian kepada Komite Etik Penelitian Kesehatan (KEPK) Fakultas Kedokteran Universitas Syiah Kuala-RSUDZA, dan melakukan pengumpulan data penelitian menggunakan internet survey (google form).

\section{Hasil Penelitian}

Penelitian ini bertujuan untuk mengetahui perbedaan fear of failure pada mahasiswa Bidikmisi di Universitas Syiah Kuala. Subjek yang terlibat pada penelitian ini berjumlah sebanyak 340 subjek. Adapun data demografi yang diperoleh dari penelitian ini dapat dilihat pada tabel berikut:

\begin{tabular}{|c|c|c|c|c|c|}
\hline No & $\begin{array}{l}\text { Deskripsi } \\
\text { Subjek }\end{array}$ & Kategorisasi & Jumlah & $\begin{array}{c}\text { Presentase } \\
\text { (\%) }\end{array}$ & $\begin{array}{c}\text { Total } \\
(\%)\end{array}$ \\
\hline \multirow[b]{2}{*}{1} & \multirow{2}{*}{$\begin{array}{l}\text { Jenis } \\
\text { Kelamin }\end{array}$} & Laki-laki & 170 & 50 & 100 \\
\hline & & Perempuan & 170 & 50 & \\
\hline \multirow{9}{*}{2} & \multirow{9}{*}{ Fakultas } & $\begin{array}{l}\text { Ekonomi dan } \\
\text { Bisnis }\end{array}$ & 35 & 10,3 & 100 \\
\hline & & Hukum & 14 & 4,1 & \\
\hline & & $\begin{array}{l}\text { Ilmu Sosial dan } \\
\text { Politik }\end{array}$ & 26 & 7,6 & \\
\hline & & Kedokteran & 26 & 7,6 & \\
\hline & & Kedokteran Gigi & 18 & 5,3 & \\
\hline & & $\begin{array}{l}\text { Kedokteran } \\
\text { Hewan }\end{array}$ & 17 & 5.0 & \\
\hline & & $\begin{array}{l}\text { Keguruan dan } \\
\text { Ilmu Pendidikan }\end{array}$ & 52 & 15,3 & \\
\hline & & $\begin{array}{l}\text { Kelautan dan } \\
\text { Perikanan }\end{array}$ & 39 & 11,5 & \\
\hline & & Keperawatan & 12 & 3,5 & \\
\hline
\end{tabular}


Perbedaan Fear of Failure pada Mahasiswa Bidikmisi ditinjau dari Jenis Kelamin

Proyeksi, Vol. 16 (2) 2021, 174-182

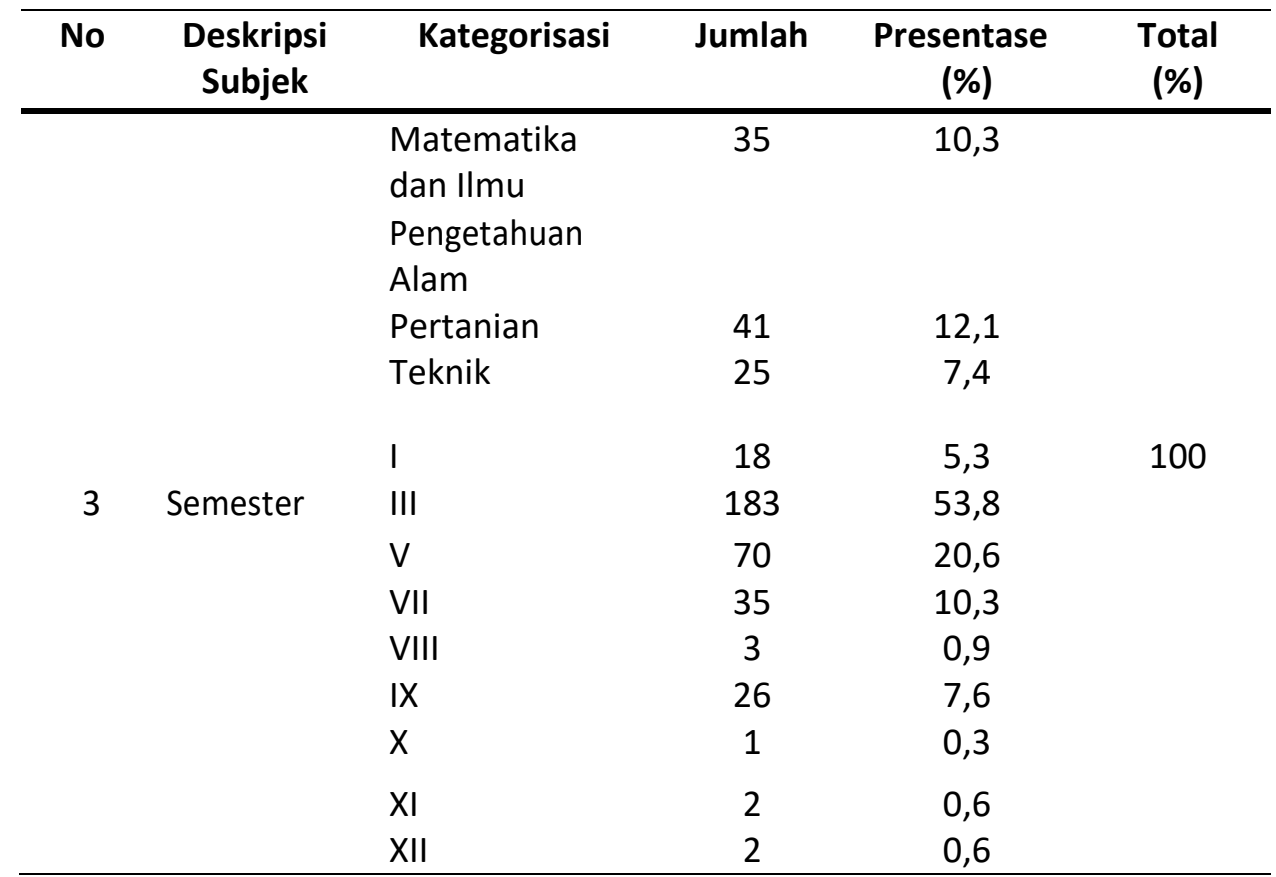

Hasil uji normalitas menggunakan teknik statistik One-Sample Kolmogorov-Smirnov Test menunjukkan bahwa data penelitian berdistribusi normal. Hal ini dapat dilihat dari skor yang memiliki sebaran data normal dengan nilai signifikansi $(p)=0.200(p>0.05)$. Hasil uji homogenitas melalui One Way Anova, didapatkan hasil dengan nilai signifikansi sebesar $(p)=0.836(p>0.05)$, Hasil tersebut menunjukkan bahwa data pada penelitian ini bersifat homogen.

Pada tahap uji hipotesis dilakukan dengan menggunakan teknik Independent Sample T-Test. Hasil uji hipotesis menunjukkan bahwa nilai signifikansi pada penelitian ini yaitu $(p)=0,511 \quad(p>0,05)$, berdasarkan skor tersebut menunjukkan bahwa tidak terdapat perbedaan fear of failure pada mahasiswa Bidikmisi di Universitas Syiah Kuala ditinjau dari jenis kelamin. Kategorisasi terkait fear of failure dapat dilihat pada tabel berikut:

Tabel 2. Kategorisasi Fear of Failure

\begin{tabular}{cccccc}
\hline Skor & Kategori & \multicolumn{2}{c}{ Laki-laki } & \multicolumn{2}{c}{ Perempuan } \\
& & Jumlah & $\begin{array}{c}\text { Persentase } \\
\text { J\%) }\end{array}$ & Jumlah & $\begin{array}{c}\text { Persentase } \\
\text { (\%) }\end{array}$ \\
\hline $\mathrm{X}<58,34$ & rendah & 27 & 15,88 & 22 & 12,94 \\
$58,34 \leq \mathrm{X}<91,66$ & sedang & 113 & 66,47 & 122 & 71,76 \\
$\leq 91,66 \mathrm{X}$ & tinggi & 30 & 17,65 & 26 & 15,29 \\
\hline Total & & 170 & 100 & 170 & 100 \\
\hline
\end{tabular}

Berdasarkan tabel tersebut, maka dapat disimpulkan bahwa secara total keseluruhan terdapat sebanyak 27 subjek laki-laki dan 22 subjek perempuan yang berada pada kategori rendah, sedangkan pada kategori sedang terdapat 113 subjek laki-laki dan 122 subjek perempuan. Selain itu, 30 subjek laki-laki dan 26 subjek perempuan berada pada kategori tinggi. 
Firman Firdaus Nuzula, Dahlia, Afriani, dan Zaujatul Amna

\section{Diskusi}

Penelitian ini dilakukan untuk mengetahui perbedaan fear of failure pada mahasiswa Bidikmisi ditinjau dari jenis kelamin. Berdasarkan hasil analisis uji independent sample t-test didapatkan nilai signifikansi $(p)=0,511(p<0,05)$. Skor tersebut menunjukkan bahwa hipotesis yang diajukan tidak diterima, artinya tidak terdapat perbedaan fear of failure pada mahasiswa Bidikmisi ditinjau dari jenis kelamin di Universitas Syiah Kuala.

Hasil penelitian ini sejalan dengan penelitian yang dilakukan oleh Fitrianda (2019), yaitu perbedaan fear of failure pada mahasiswa Fakultas Teknik ditinjau dari jenis kelamin di Universitas Syiah Kuala. Hasil penelitian menunjukan bahwa tidak ada perbedaan fear of failure pada laki-laki dan perempuan. Menurut Fitrianda, tidak adanya perbedaan fear of failure pada laki-laki dan perempuan disebabkan oleh semakin meningkatnya efikasi diri perempuan untuk terlibat dalam bidang teknik. Hasil penelitian serupa didapati oleh Hendra (2019) mengenai perbedaan fear of failure pada atlet ditinjau dari jenis olahraga. Pada analisis tambahan yang dilakukan, ditemukan bahwa tidak ada perbedaan fear of failure pada atlet laki-laki dan atlet perempuan di Banda Aceh.

Penelitian lain yang memiliki hasil senada adalah penelitian yang dilakukan oleh Correira, Rosado, Serpa dan Ferreira (2017) mengenai perbedaan fear of failure pada atlet, yang menunjukkan bahwa secara umum tidak ada perbedaan fear of failure pada laki-laki dan perempuan. Pada penelitian tersebut tidak ditemukan interaksi yang signifikan antara jenis kelamin pasangan pada variabel ini. Selanjutnya, penelitian yang dilakukan oleh Sagar, Boardly dan Kavussanu (2011) juga menunjukkan bahwa tidak ada perbedaan fear of failure pada laki-laki dan perempuan. Menurut penelitian tersebut, dampak yang mungkin dimunculkan dari fear of failure secara umum ini tidak dapat dibedakan oleh jenis kelamin, sehingga tidak ada perbedaan di antara laki-laki maupun perempuan.

Penelitian Fried-Buchalter pada tahun 1997 yang meneliti tentang fear of succes, fear of failure, dan imposter phenomon pada 104 manager marketing di beberapa negara di benua Afrika dan Amerika, menemukan bahwa tidak ada perbedaan fear of failure secara signifikan pada manager marketing perempuan dan manager marketing laki-laki. Perbedaan tersebut dikarenakan adanya motivasi prestasi, setiap individu baik laki-laki maupun perempuan memiliki dorongan untuk berprestasi. Hal ini sejalan dengan penelitian yang dilakukan oleh Upadhayay dan Guragain (2014) tentang perbandingan fungsi kognitif pada mahasiswa kedokteran laki-laki dan perempuan. Penelitian tersebut menemukan bahwa tidak ada perbedaan mengenai motivasi kognitif laki-laki dan perempuan secara signifikan, selain itu mereka juga menemukan bahwa fungsi kognitif antara laki-laki dan perempuan cenderung sama. Persamaan mengenai motivasi kognitif juga dinyatakan oleh Gurian dan Philip (2002) yang mengatakan bahwa di balik banyak perbedaan antara laki-laki dan perempuan, persamaan motivasi kognitif di antara keduanya mengesampingkan perbedaan tersebut.

Mahasiswa Bidikmisi Universitas Syiah Kuala baik laki-laki maupun perempuan memiliki tujuan pencapaian prestasi yang sama yaitu mempertahankan agar bantuan dana mereka tetap berjalan dan tidak dicabut. Hal ini senada dengan penelitian yang dilakukan oleh Borgonovi dan Wong Han (2021), yang menyatakan bahwa dalam pencapaian sebuah prestasi, laki-laki dan perempuan sama-sama membatasi pilihan mereka dan mengambil resiko yang lebih sedikit sesuai kemampuan mereka untuk meminimalisasikan kemungkinan kegagalan yang dapat terjadi. Selain itu, individu melakukan performansi dan persepsi diri terhadap lingkungan dunia pendidikan yang akan memberikan pengaruh pada penetapan tujuan dan sasaran pencapaian prestasi (Conroy, 2002). 
Perbedaan Fear of Failure pada Mahasiswa Bidikmisi ditinjau dari Jenis Kelamin

Proyeksi, Vol. 16 (2) 2021, 174-182

Bidikmisi dalam kebijakannya menerapkan kesetaraan peraturan tanpa melihat jenis kelamin. Semua mahasiswa Bidikmisi baik laki-laki maupun perempuan mendapatkan kewajiban yang sama. Menurut Thoriquttyas dan Rohmawati (2018), jika diarahkan pada ranah manajemen dalam suatu lembaga pendidikan, maka manajemen berdasarkan perspektif jenis kelamin dapat dibedakan menjadi tiga model, di antaranya, kebijakan netral jenis kelamin, kebijakan bias jenis kelamin, dan kebijakan responsif jenis kelamin. Kebijakan netral merupakan kebijakan yang dibuat tanpa mempertimbangkan perbedaan situasi dan kebutuhan antara laki-laki dan perempuan. Hal inilah yang juga dapat menjadi dasar tidak adanya perbedaan fear of failure pada mahasiswa Bidikmisi laki-laki dan perempuan di Univesitas Syiah Kuala.

Penelitian ini dilakukan dengan kaidah ilmiah, namun peneliti menyadari bahwa penelitian ini masih terdapat beberapa hambatan dan kelemahan, sehingga menjadi hal yang dapat dipertimbangkan untuk penelitian selanjutnya. Adapun hambatan yang dialami peneliti di antaranya, peneliti mengalami kesulitan pada saat mencari subjek penelitian dikarenakan masa pandemi yang terjadi pada saat penelitian berlangsung. Selain itu, minimnya partisipasi mahasiswa Bidikmisi laki-laki yang mayoritas tidak bersedia untuk menjadi subjek, sehingga peneliti perlu melakukan pendekatan lebih luas lagi kepada calon subjek laki-laki yang lainnya dan hambatan terakhir adalah keterbatasan peneliti dalam mengakses informasi mengenai mahasiswa Bidikmisi di Universitas Syiah Kuala.

Kelemahan pada penelitian ini di antaranya, proporsi partisipasi mahasiswa Bidikmisi disetiap angkatan dan fakultas tidak merata, pemilihan subjek yang terpusat pada Asrama Bidikmisi, penentuan metode sampling yang kurang tepat pada populasi yang jumlah besar dengan keterbatasan informasi mengenai mahasiswa Bidikmisi di masa pandemi, kriteria subjek penelitian yang umum, salah satunya yaitu tidak ada batasan semester atau angkatan, dan penelitian yang hanya berfokus pada perbedaan fear of failure ditinjau dari jenis kelamin dan tidak melihat fear of failure pada persepektif sosial dan budaya.

\section{Kesimpulan dan Saran}

Hasil penelitian menunjukkan bahwa tidak ada perbedaan fear of failure pada mahasiswa Bidikmisi di Universitas Syiah Kuala. Hal ini dikarenakan faktor prestasi yang ingin dicapai oleh mahasiswa, serta kebijakan netral dalam suatu lembaga pendidikan yang tidak dapat ditentukan berdasarkan jenis kelamin. Selanjutnya, dalam penelitian ini ditemukan bahwa tingkat fear of failure pada mahasiswa Bidikmisi di Universitas Syiah Kuala mayoritas berada pada kategori sedang.

Berdasarkan hasil penelitian, analisis, dan pembahasan penelitian, peneliti menyarankan beberapa hal kepada subjek penelitian dan peneliti selanjutnya. Subjek penelitian dapat menyadari bahwa fear of failure bisa terjadi pada siapa saja dan tidak melihat jenis kelamin. Selanjutnya subjek penelitian diharapkan mendapat informasi akan efek positif dan efek negatif dari fear of failure, sehingga subjek penelitian dapat mengantisipasi kemungkinan hal buruk yang terjadi dikemudian hari. Kepada peneliti selanjutnya, disarankan untuk melakukan penelitian replikasi menggunakan variabel fear of failure dilingkungan pendidikan di Universitas Syiah Kuala dengan menganalisa dari segi sosial dan budaya, menggunakan desain kualitatif untuk memperdalam fenomena fear of failure yang terjadi pada subjek yang berada di lingkungan pendidikan, memperhatikan penggunaan metode pengumpulan data yang tepat, sesuai dengan jumlah populasi dan kondisi lapangan serta melakukan penelitian menggunakan variabel fear of failure dengan mengaitkan variabel motivasi berprestasi pada lingkungan pendidikan. 
Firman Firdaus Nuzula, Dahlia, Afriani, dan Zaujatul Amna

\section{Daftar Pustaka}

Borgonovi, F., \& Han, S. W. (2021). Gender disparities in fear of failure among 15-year-old students: The role of gender inequality, the organisation of schooling and economic conditions, Journal of Adolescence, 86, 28-39.

Conroy, D. E. (2001). Progress in the development of a multidimensional measure of fear of failure: The Performance Failure Appraisal Inventory (PFAI). Anxiety, Stress and Coping, 14(4), 41-452.

Conroy, D. E., Poczwardowski, A., \& Henchen, K. P. (2001). Evaluate criteria and emotional response associated with failure and success among elite athletes and performing artist. Journal of Applied Sport Psychology,13, 300-322.

Conroy, D. E. (2002). Representational Models Associated With Fear of failure in Adolencents and Young Adults. Journal of Personality,71(5).

Coreira, M., Rosado, A. F. B., Serpa, S., \& Ferreira V. (2017). Fear of failure in athletes: Gender and type of sport differences. Revista Iberoamericana de Psicologia del Ejercicio y el Deporte, 12(1), 185193.

Davidoff, L. L. (1991). Psikologi suatu pengantar (jilid. 2). Terjemahan: Juniati, M. Jakarta: Erlangga.

Departemen Pendidikan Nasional (2005). Kamus besar bahasa Indonesia (edisi. Ketiga). Jakarta: Balai Pustaka.

Elliot, A. J., \& Trash, T. M. (2004). The intergenerational transmission of fear of failure. Personality Social Psychology Bulletin: 30 (8): 957-71. doi: 10.1177/0146167203262024.

Fernanda, N. (2017, Mei). Jenis-jenis beasiswa yang perlu kamu ketahui. Rencanamu.id. diakses tanggal 17 Juni 2020 dari https://rencanamu.id/post/persiapan-kuliah/jenis-jenisbeasiswa-yang-perlu-kamu-ketahui.

Fitrianda, A. (2019). Perbedaan fear of failure pada mahasiwa fakultas teknik ditinjau dari jenis kelamin di Universitas Syiah Kuala.(Electronic These and Dissertatitions). Universitas Syiah Kuala, Banda Aceh.

Fried-Buchalter, S. (1997). Fear of success, fear of failure and the imposter phenomenon among male and female marketing manager. Sex Roles, 39, 847-848.

Gurian, M. \& Philip, C. (2002). Boys and girls learn differently: A guide for teachers and parents. United States.

Hendra, W. (2019). Perbedaan ketakutan akan kegagalan (fear of failure) pada atlet ditinjau dari jenis olahraga.(Electronic Thesis and Disertatiton). Fakultas Kedokteran Universitas Syiah Kuala, Aceh. 
Perbedaan Fear of Failure pada Mahasiswa Bidikmisi ditinjau dari Jenis Kelamin

Proyeksi, Vol. 16 (2) 2021, 174-182

Husna, A. (2015). Perbedaan fear of failure pada sarjana pengangguran di Banda Aceh ditinjau dari jenis kelamin.(Electronic These and Dissertatitions). Universitas Syiah Kuala, Banda Aceh.

Kalar, M. U., \& Mustahsan, S. M. (2013). Understanding fear in school children. International Journal of Collaborative Research on Internal Medicine \& Public Health, 5(5), 268-278.

Kemenristekdikti. (2019). Panduan pendaftaran beasiswa bidikmisi. Jakarta, Indonesia.

Kemenristekdikti. (2019). Petunjuk teknis pengelolaan bidikmisi. Jakarta, Indonesia.

Minnaert, A., \& Janssen, P. J. (1997). Bias in the assessment of regulation activities in studying at the level of higher education. European Journal of Psychological Assessment, 13(2), 99-108.

Mobbs, D., \& Hagan, C. C. (2015). The ecology of human fear: Survival optimization and the nervous system. Proseding Frontiers in Neuroscience. doi: 10.3389/fnins. 2015.00055.

Nainggolan, L. (2017). Hubungan antara persepsi terhadap harapan orang dengan ketakutan akan kegegalan pada mahasiswa program studi psikologi Universita Dipenogoro semarang. Jurnal UniversitasDipenogoro, Semarang.

Nelson, K. L., Newman, D. N., Mcdaniel, J. R., \& Buboltz., W. C. (2013). Gender differences In fear of failure amongst enggineering student. International journal of Humanities and Social Science, 16(3), 10-16.

Pemerintah Republik Indonesia (2003) Undang-undang Republik Indonesia No. 20 tahun 2003 tentang Sistem Pendidikan Nasional. Jakarta.

Sagar, S. S., Boardley, I. D., \& Kavussanu, M. (2011). Fear of failure and student athletes' interpersonal antisocial behavior in education and sport. British Journal of Educational Psychology, 81, 3914-8.

Takriyuddin, Mukmin \& Yunus (2016). Pengaruh beasiswa bidikmisi terhadap prestasi belajar mahasiswa program studi pendidikan pancasila dan kewarganegaraan fakultas keguruan dan ilmu pendidikan universitassyiah kuala. Jurnal IImiah Mahasiswa Pendidikan Kewarganegaraan Unsyiah, 1(1), 49-60.

Thoriquttyas, T., \& Rohmawati, N. (2018). Segregasi gender dalam manajemen perserta didik di lembaga pendidikan islam. Martabat:Jurnal Perempuan dan Anak, 6(2), 289-314.

Upadhayay, U., \& Guragain, S. (2014) Comparison of Cognitive Functions Between Male and Female Medical Students: A Pilot Study. Journal of Clinical \& Diagnostic Research, 8(6), BC12-BC15.

Zulkarnain \& Novliadi (2009). Sense of humor dan kecemasan menghadapi ujian di kalangan mahasiswa. Majalah Kedokteran Nusantara, 42(1), 48-54. 